\title{
Influence of Gender Roles and Responsibilities on Family Planning Decisions in Adults, in Karachi, Pakistan: a Qualitative Analysis of Open-ended Interviews
}

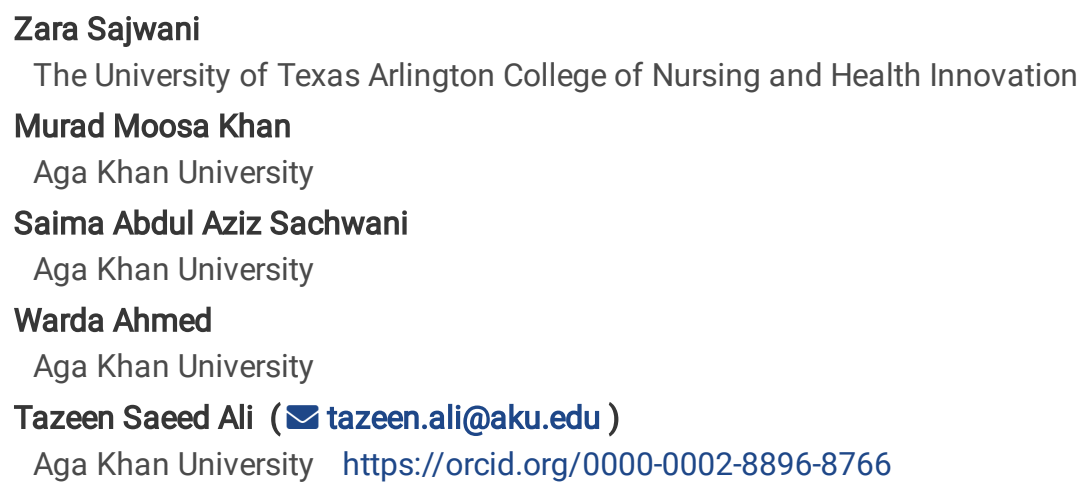

Research

Keywords: Gender roles, Gender responsibilities, Pakistan, FP, FP decisions, Reproductive health

Posted Date: April 6th, 2021

DOI: https://doi.org/10.21203/rs.3.rs-375254/v1

License: (우 (1) This work is licensed under a Creative Commons Attribution 4.0 International License. Read Full License 


\section{Abstract}

Background

In Pakistan, the slow pace of declining fertility rate accounts for troubling consequences like multiple pregnancies, induced abortions, the low $34 \%$ contraceptive prevalence rate, and overpopulation. This coupled with the lack of literature on this topic in the country makes it pivotal to explore the gender roles and responsibilities of adults in marital life and within the family and their influence on Family Planning decisions in adults, in Karachi, Pakistan.

Methods

The study design involved purposive selection of 12 consenting married adults belonging to Gulberg Town, from whom detailed qualitative data was collected using open-ended, semi-structured interviews, supported by field notes. For the sake of anonymity, participants were assigned codes. Furthermore, all discussions were conducted in English or Urdu language by the female investigator herself and were audio recorded after obtaining participants' consent. Thereafter, a rigorous thematic analysis of the interviews was carried out, with the results being double-checked before being securely stored in soft or hard copy.

Results

The study observations identified that gender roles and responsibilities do affect Family Planning decisions in Pakistan. The results were broadly categorized into two themes: superficial reasons and deeper reasons affecting FP decisions. The first theme has three main categories; interpretation of FP, awareness about FP, and couple as representative of FP decision making whereas the second theme has five categories; roles and responsibilities of men in the family, roles and responsibilities of women in the family, women autonomy, mind the gap or taming the women, and way forward.

\section{Conclusions}

Our study findings suggest that while superficial reasons must be resolved, it is primarily crucial to eliminate the subtler, tap root factors influencing FP decisions by strongly addressing school curricula, nurses and other Health Care Workers (HCWs) to positively impact the society. Further qualitative and quantitative research is ultimately necessary for assessing the viewpoint of important stakeholders and how, using a multiprong approach, the stringent perceptions pertaining to Family Planning can be altered to benefit the society.

\section{Plain English Summary}

In Pakistan, the slowly declining fertility rate is leading to major problems like multiple pregnancies which makes Family Planning an important issue to address. Moreover, in the Pakistani society, people often negotiate upon their rights by accepting and adopting the gender roles and responsibilities ascribed to them by the society. In this study, open-ended interviews were used to explore the gender roles and responsibilities in the Pakistani society and their influence on adults' marital life and family planning decisions.

Twelve married adults from Gulberg town, Karachi, were interviewed and both their verbal and nonverbal responses were recorded in the form of field notes. The participants were ensured confidentiality and encouraged to discuss openly.

The study results suggested that gender roles and responsibilities do affect Family Planning decisions. Overall, two themes were identified: superficial reasons and deeper reasons influencing Family Planning decisions. The first theme has three main categories; interpretation of $\mathrm{FP}$, awareness about FP, and couple as representative of FP decision making while the second theme has five categories; roles and responsibilities of men in the family, roles and responsibilities of women in the family, women autonomy, mind the gap or taming the women, and way forward.

In conclusion, both the superficial and deeper factors affecting FP decisions need to be resolved. Addressing the school curriculum, health care workers and key stakeholders may help modify people's understanding and attitude about gender roles and responsibilities, hence bringing about a positive change in decision making regarding FP.

\section{Background}

Gender is defined as roles, responsibilities, attributes, and behaviours deemed appropriate for men and women, as identified by the society $(1,2)$. On grounds of gender, men, being masculine, (3) are expected to be dominant, to perform tough jobs (4), and to have the productive role of earning for the family (5-8), thereby, being perceived as capable leaders and decision makers (9). On the other hand, women are 
expected to be caring, delicate, and sentimental (9) while being outspoken, assertive, and loud is rendered inappropriate for them. Linked to this notion of acceptable traits, there are two schools of thoughts about gender roles and responsibilities: the traditional notion highlighting rigid gender roles and the egalitarian approach, emphasizing the modern and changing attributes. While Sweden is moving towards the egalitarian approach (10), Pakistan, ranked 125th, in a pool of 169 countries, in the Gender Development Index (11), evidently belongs to the former category. Furthermore, while studies done in Moscow, Toronto and Sweden concluded that men should exhibit antifeminine attitude (5-7), a study done in the US additionally emphasized that men and the older population are more inclined towards traditional gender roles $(12,13)$. Likewise, in the Pakistani society, a man being considered the authoritative person, the bread winner, and the protective figure of the family, may be aggressive and egoistic towards his wife while a woman's dominance is considered unacceptable because she is presumed to ensure harmony and carry out domestic tasks $(4,14)$. In consistence with a study in Kenya, a UK based study conducted on South Asian participants also concluded that men, apart from having the protective role, were also allowed to abuse their wives if they did not comply with the traditional gender norms of society (15-17). Moreover, in an Asian country as well as in other western countries moving away from the traditional division of tasks, the bigger share of work of employed women in domestic work and limited support from men in household responsibilities are burgeoning concerns $(18,19)$.

Reproductive health means that individuals can have an accountable, gratifying, and protected sex life, and that they can reproduce and have the autonomy to choose if, how often, and when to do so (20). Globally, more than 500,000 women die in developing countries due to pregnancy related issues every year, out of which 28 thousand are from Pakistan (21). While in Bangladesh, the fear of side effects and male dominance decreases the use of FP methods, the rigid gender norms of the Pakistani society affect reproductive health $(22,23)$ and FP decisions, in terms of utilization of contraceptives, its types, and birth spacing. This is also why women's input in FP matters may lead to domestic violence in male dominant societies (24). Due to the notion that the woman, along with being submissive, is supposed to satisfy the sexual needs of her partner, one hundred and twenty million women have verbalized that they do not want to get pregnant but cannot utilize FP methods due to socio-cultural barriers $(21,25)$. Furthermore, in Uganda, the traditional ideology of fertility is central to defining femininity and masculinity itself (26). Complementing this, a study of Spanish men also concluded that the idea of masculinity propelled unsafe sex and hence greater physical expression of sexual desires, something that leads to an increase in domestic violence, deprives a woman of her rights, exposes women to Sexually Transmitted Infections (STIs) and raises mental health issues amongst them as well (27-30).

Such barriers, coupled with incorrect religious notions (21) tend to discourage contraceptive use especially due to the disregard of a woman's autonomy, lack of mutual decision making in the family, and lack of awareness and low educational levels with regards to FP and contraceptive usage amongst couples and particularly amongst women $(31,32)$. Other factors, including, mobility, socio economic status, and educational status, also play a significant role in FP decisions and contraceptive use (33). Moreover, in Nepal, although a study implies that the gender roles present do not allow for mutual decision making, another study suggests that there is a positive shift in thinking in that women empowerment is a growing notion and hence men are becoming more involved in reproductive matters $(34,35)$. However, in general, while mutual decision making is a must, it is hardly observed. Studies in both US and Pakistan revealed that women's participation in the process of decision making, and the husband's participation in household chores are factors affecting family size and related decisions $(21,23)$. A study in Pakistan in 2001-2 found that females with decision making power could determine their fertility and frequency of childbirth after marriage, hence giving them control over their body(36). The unilateral gender power gradient, fear of violence, and existing cultural norms supporting solely male dominance in decision making regarding FP matters $(37,38)$ are reasons for the low rate of contraceptive prevalence in Pakistan of around 34\%. This is slowing down the rate of fertility decline, and thus may lead to outcomes like multiple pregnancies, induced abortions, prevalence of STIs $(24,38,39)$ and overpopulation, a major large-scale problem in Pakistan. As unravelled by a mixed methodology study in South Africa, men had more knowledge concerning contraceptive methods and their usage of condoms was acceptable while sociological gendered roles and responsibilities hindered a woman's choice in making decisions concerning her reproductive health, thus implying the need for women being given a right over their body. However, doing so may also have adverse results like leading to carefree sexual behaviour of men and setting them free of the reproductive role (40). The latter consequence must be considered because in Brazil, it is the decreased pleasure of love-making that accounts for low contraceptive usage(31). Moreover, it was found that, in Australia, lack of empowerment and rigid gender roles disallow a woman from using condoms and not even one woman was able to negotiate condom usage with their sexual partner (24) while men in Australia had no knowledge of pregnancy prevention, perceiving it to be woman's domain (30). Thus, this study will help promote mutual FP decisions and hopefully increase awareness about the true spirit of family formation in religion as well (21).

In contrast to male dominance affecting FP decisions, in countries, like Tanzania, Brazil and Australia, female dominancy may exist in some families because men considering the FP domain and pregnancy prevention as being part of women's reproductive role, they do not contribute to FP decisions either because of feeling less empowered or because of sometimes thinking that FP means Female Planning. $(26,30,31,41,42)$. In Tanzania, men did, however, make decisions about the number and frequency of having children and their lack of 
participation in FP decisions allowed some women to get involved in FP decision making (42). However, while being solely responsible for these decisions gives a woman authority over her body, it also puts her at the risk of being blamed in case of side effects of using contraceptives and simultaneously may threaten the rights and privileges of a man in reproductive health. Moreover, there is an influence of developed countries on developing countries; this is a burgeoning source of redefining gender roles affecting reproductive health conduct amongst the people of Pakistan (22)

This study is hence essential for three important reasons. Firstly, people, being unaware of their rights pertaining to reproductive health, make decisions as ascertained by their predetermined roles and responsibilities, assuming that they are supposed to negotiate in some cases as well. Secondly, with changing gender norms, women have higher education and are becoming financially independent which makes this investigation addressing the discovery of any change in traditional gender roles and responsibilities and their influence on FP important. Thirdly, the available literature on this topic in Pakistan is insufficient. This topic being an overlooked one in Pakistan, requires conducting further studies on it (43) so as to help develop programs(44) and policies that will protect the reproductive rights of men and women. Therefore, my study intends to serve this purpose by aiming to identify the gender roles and responsibilities of adults in marital life and within the family and their influence on FP decisions in adults, in Karachi, Pakistan.

\section{Methods \\ Study Design}

A qualitative descriptive study was conducted in 2015 using an open-ended approach of inquiry with married adults of age 18-45 years, living in Gulberg town in urban Karachi, Pakistan. Since there is dearth of awareness on this topic in Pakistan, a qualitative inquiry facilitated a rich response from the participants and hence was considered the most appropriate design to answer the study questions and to help assess the influence of gender roles and responsibilities on FP decisions. The rationale for choosing Gulberg town, comprising of eight union councils, was the diversity in cultural and socio-economic backgrounds found there, making it a good representative of Karachi, and of the different ethnic groups in Pakistan.

\section{Participant Selection}

Purposive sampling was used in this study and so, as per Polit and Beck (2012), married adults from Karachi belonging to the reproductive age group were chosen since they had some insight about the topic. Married participants aged 18 to 45 years and able to speak and comprehend either English or Urdu language were eligible to voluntarily participate because 18 is the legal age of marriage according to Social Justice Pakistan [2014] and 45 is the upper limit of the reproductive age in the women of Pakistan $(45,46)$. For the sake of congruency, the maximum age of men was also kept at 45 years. Individuals who were unmarried, widowed, divorced, currently separated or not willing to participate were not included in the study. Moreover, maximum variation in sampling is desirable in qualitative approach purposive sampling, and consequently, participants from a blend of different family types, age ranges, ethnic backgrounds, number of children, and duration of marriage were selected thus helping to bring about variety and enrichment in the responses (47, 48). Participants were approached through community activists and key persons who had been living in the community for a long time, and thereby knew the community and residents well enough to facilitate the enrolment of participants. Data collection was carried out in three union councils of Gulberg town based on their diversity in the socio-economic status. Aisha Manzil falls in the status of lower middle class, Naseerabad is a middle-class community, and Karimabad is in the status of the upper middle class(14). Moreover, the venue for data collection was a separate place, preferably the community stakeholders' home to provide privacy to the participants so that they could talk openly on this sensitive topic. Interested participants were also given an overview of the study and asked to sign or mark their thumb on the informed voluntary consent form, which included details about the purpose, procedures, ethical aspects of the study, and other related details. Furthermore, participants were informed that the interview would be audio-taped, and their anonymity would be maintained. This was applied by assigning codes to the participants. It was also decided that if, at any point, any participant, on recalling an unpleasant happening, is unable to continue, the interview would be paused there and either it would be waited for the participant to become stable once again or otherwise the interview would be scheduled for another date. Also, the participants were given the right to withdraw from the study at any time without having any repercussions. Hence, all the participants participated voluntarily, and prior to the collection of data, approval from the Ethical Review Committee (ERC) (see Appendix) of the Aga Khan University Hospital (AKUH) was obtained by providing them the details of the study.

\section{Data Collection}


Since data saturation is more important than generalizability in a qualitative study, hence an insight into the study subject was achieved on interviewing twelve participants. Each interview lasted for around 40 to 60 minutes, thus providing ample time, in terms of credibility, for adjustment, engagement, clarification, and exploration of the study questions $(49,50)$. Data collection was carried out by using semistructured interviews and field-notes with the latter capturing the nonverbal details of participants, like, their facial expressions as well. Additionally, to ensure credibility, a writing pad containing the researcher's personal biases was maintained to keep these biases aside thereby ensuring fairness of the data. The process of member check used in this study helped ensure credibility and confirmability of data as the participants were requested to ratify their responses (49). Open-ended, semi-structured interviews along with guides were used to explore the influence of gender roles and responsibilities on FP decisions. Interviews were conducted in English or Urdu languages and were audio-recorded after obtaining the participants' consent. The participants' anonymity was also maintained by assigning codes to them. All investigations were carried out by the female investigator herself. However, a male health care professional (data collector) with a Bachelor's degree in health had also been trained for at least 2 weeks to accompany the primary investigator and he was in charge of discussing sensitive issues with males which they may not feel comfortable in sharing otherwise. The investigators were well-versed in both English and Urdu languages and all study participants were encouraged and given opportunities to openly discuss their opinions in confidence.

\section{Data Analysis}

All the discussions were recorded and firstly, thematic analysis of the collected data was carried out using Graneheim and Lundman guidelines. For each participant, the data, in the form of a script, was saved in a Microsoft Word document. The process of word-to-word transcription of raw data and translation was carried out and the data was read thoroughly multiple times to get the nuances of the content and context. Moreover, the common errors in transcription were managed by making conscious efforts to avoid manipulation of data, getting the data proof checked by the participants, and utilization of field notes, respectively. This helped preserve the original context of the data in the analysis process. From the transcribed raw data, codes were identified and charted in next to the transcribed script. Consequently, categories were developed and, ultimately, themes were generated, which presented a general idea or viewpoint of the data. Additionally, the analysis of field notes was carried out by reading them and highlighting the main domains. The domains from the field notes were mentioned next to the participant's response to authenticate their congruency with the interview. After the entire process, the data was double checked by the investigator, and it was also given to the participants for verification in case of need. The process of data collection is important because the data analysis of a qualitative study is a vigorous, collaborative, and iterative process (48).

Following the process of data collection, the interview recordings were saved on a USB, personal computer, and on the email account of the researcher, to prevent loss of the data. The data in soft copy was protected through password protected systems and the data in the hard copy, such as photocopies of field notes made as back up, was kept under lock and key. The confidentiality of data was limited to the research team and was used for academic and professional purposes only. Lastly, data breaches were limited and back and forth meetings with the supervisor and committee members helped verify the participants' responses in the development of codes, categories, and themes. The data was also ratified by the supervisor and committee members to prevent contamination of data from the researcher's biases and beliefs.

\section{Results}

The 12 participants recruited for this research were married adults from the Gulberg town, 6 males and 6 females, whose diverse demographic details are stated in Tables 1 and 2, respectively. The data analysis generated two themes: Peripheral roots (factors observable by the society) affecting FP decisions and Taproots (deep factors hidden from society) for gender roles and responsibilities in explaining FP decisions. The first theme has three main categories; interpretation of FP, awareness about FP, and couple as representative of FP decision making whereas the second theme has five categories; roles and responsibilities of men in the family, roles and responsibilities of women in the family, women autonomy, mind the gap or taming the women, and way forward.

\section{Theme 1}

\section{Category 1: Interpretation of FP}

The participants stated that FP decisions affect both partners and for most, FP meant the gap between children and having an ideal family size, for which the couple can choose a method of contraception. In fact, some believed that financial constraints and its impact on a child's upbringing are paving the way for couples to rethink their ideal family size and to use FP to curtail their expenses associated with more children. 
"A child is born with empty hands in this world. He/she needs everything including good education, food, and clothing etc...If parents will keep on producing children, they will not be able focus on all the needs of each child." (Participant 09)

Additionally, educated participants thought that FP is beneficial for women's physical and mental health, as it provides a sufficient gap between the births of children, thus making her haemoglobin and nutritional reserves appropriate for healthy pregnancy and thereby preventing issues associated with unplanned pregnancy and abortion. Female respondents, being more concerned about their health, were motivated to use FP so that they can regain their health.

As per participants' general opinion, the pressure on newly married women to prove their fertility leads to younger couples avoiding the use of FP methods. Women also felt that men are concerned about FP only when there is a threat of maternal mortality. Moreover, they believe that the number of children signifies the love of a wife towards her husband.

Furthermore, some participants believed a male child is a source of income for poor uneducated individuals, a concept leading to multiple pregnancies until the desired number of male children is achieved. Some uneducated participants also strongly felt that children are a gift from God, having more children pleases God and in-laws and so they should not control their birth. Uneducated participants reported,

"My husband says that this is God given. He is merciful on us; He has given us the blessing of children."(Female participant 11 from the lower middle SES)

"FP is against nature... It is interference with nature."(Male participant 05 from the lower middle SES)

Both genders believed that modern FP methods lead to side effects like weakness, infection, blood clots during menstruation, mental illness, cancer, infertility, and even death in the long run. While male respondents verbalized the ring method causing problems for them during sexual intercourse, female participants regarded the use of pills and injections as less reliable because they caused weight gain and skin darkening, hence affecting their appearance. Furthermore, an uneducated woman verbalized the old perception that pregnancy will make a female look aged before time and thus the use of FP may help them preserve their youth.

"She (mother-in-law) used to fight with me and said that you (participant) do not produce children because you want to stay young, as delivering babies will make a woman aged before time. She asked that am I an old woman, because I have been using FP?" (Uneducated female participant 12 from the lower middle SES)

As per uneducated participants, the lack of time and knowledge about FP, and the myth regarding condoms causing Acquired Immune Deficiency Syndrome (AIDS) and Tuberculosis (TB) were also factors inhibiting couples from using FP decisions.

\section{Category 2: Awareness about FP}

Generally, participants verbalized that due to information sources like education by health care professionals, media (TV channels), and NGO (Non-Governmental Organization) workers, they have some awareness about methods including pills, condoms, ring, coil, injection, withdrawal, and sterilization. Female participants from the upper middle SES regarded lady doctors as a source of information for them on FP while uneducated participants from the lower middle SES acquired information on FP from elders of the same gender amongst their family and friends Among physical methods, condoms were considered comparatively better for use among male participants, but also decreased their pleasure and needed to be used with consistency. Participants with spouses from the health care field were more likely to make informed decisions. An educated participant, whose wife was a midwife by profession, favoured condoms because it has no side effects, prevents STIs and because using condoms does not require seeking medical assistance as demanded by other methods. Regarding chemical methods, women preferred pills, ring, and injections due to their effectiveness. However, few women also prioritized natural methods because they have fewer side effects than other available methods. Furthermore, when the couple was certain of having achieved their desired family size, participants preferred Hysterectomy and other surgical procedures over operation because it is a permanent method. While many participants verbalized lack of authentic and culturally sensitive information sources about FP, some communities, having access to health centres, were found arranging lectures at the community level to disseminate health messages so that these may be passed from one generation to the other.

"You cannot talk openly on this matter [FP]. Ladies talk amongst themselves and so do gents and then they learn from experiences of each other and try it [FP methods]." (Participant 02)

\section{Category 3: Couple as a Representative of FP Decision Making}


Educated participants particularly felt that a couple should rear and nurture their children and that they should take equal and mutual decisions regarding FP as it is their personal concern and affects the reproductive systems of both the partners. The perceived role of a couple in FP decisions was deeply linked to dynamics of gender norms of males and females, as identified in the study findings.

Furthermore, as highlighted by male participants only, giving children proper attention, time, and providing for their education, food, and other necessities makes participants rethink their FP decisions, particularly about ideal family size. The participants informed that many couples follow FP methods in a sequential manner, which begins from condoms, then use of Emergency Contraceptive Pills (ECPs), and later abortion. Thus, the participants had a fixed pattern of decision making on FP methods determined by the couple and strengthened by the duration of marriage. They shared that in case of any FP method failure (unplanned pregnancy), it was the couple's decision to continue the pregnancy or not. As per female participants, mutual decision making becomes easier if a man, being less egoistic, does not demand his wife to be a follower of decisions he takes without her active involvement on the matter.

"He (husband) said to me that I can do what I feel is appropriate (referring to the use of coil method). I thought to try this (coil)... I have heard of its side effects and I have also seen girls suffering from side effects of medicines. Therefore, I was scared. I thought of not using medicines and my husband was also comfortable with the coil method." (Educated female participant 08)

\section{Theme 2}

\section{Category 1: Role and Responsibilities of Men in the Family}

Generally, majority of the participants stated that male roles and responsibilities were of "a son, father, husband, brother, and a father-inlaw", that any work outside the house is designated for them, that having the productive role gave them an upper hand in making FP decisions, that they are mostly rigid and are required to make all major family decisions involving money including schooling, investment, spending on furniture, job selection, and health expenditure as dictated by their forefathers, traditional societal norms, and social institutes. For some participants, even the selection of food menu was by the husband's choice and an uneducated male participant also mentioned that in case of the father's absence, the son takes the lead. However, female participants reported that these roles are given by the society and not by the "supernatural power" and that the decision-making process is unclear and affected by men's dominance. Even educated men thought that while considering doctors' opinion is important before taking major decisions, in case of any conflict, the husband should take FP decisions even if the wife was more educated than him and/or belonged to the health profession. The participants felt that masculinity means to have the ability to reproduce and to have power and ability to perform labour intensive tasks. However, women felt that a "good man" should be polite, fair, protective, a problem solver, brave, honest, responsible, confident and should not misuse his power, thereby acknowledging that men have more authority. While male participants, in particular, believed that a good son should be caring, and should give time and attention to his parents, participants, in general, perceived a good husband to be loyal, calm, liberal, and friendly, and a good father to be one who ensured a good environment for his children. "A good male should be fair, earning well, and should have good attitude". (Participant 02) In contrast, participants perceived a bad man to be one involved in substance abuse and misbehaviour with others, including his wife.

\section{Category 2: Role and Responsibilities of Women in the Family}

Generally, majority of the participants stated that female roles and responsibilities were of "a wife, sister, daughter-in-law, daughter, and a mother", that they are expected to perform all household chores, that they should rear children because they have delivered them (reproductive role), that they are not given a major role in making family decisions and that they, as mentioned particularly by female participants, are forced by societal values to follow traditional gender roles allocated to them while being supportive, passive, loyal, organized, gentle, loving, caring, selfless, obedient, soft-spoken, tolerant, and calm at all costs. In contrast, a bad woman, as mentioned by male participants, is boastful and abusive who compares her husband with others, is assertive and does not dress in a modest way. Male respondents also stated that an earning woman, being more aware of her rights, is assertive and outspoken and is socially recognized as one having no "Male protector and heir" (Male participant 04) at home.

"I do not favour that women should step out of house for earning because it will make her assertive... I will perceive that being outspoken is told/ taught to her on her job."(Uneducated male participant from the lower middle SES participant 05)

The participants informed that this situation creates conflict, as depicted by the media, with whose assistance women are now being involved in important family decisions, though still not as equally as men. While men generally emphasized that women can only decide on minor issues, like selecting the paint colour and house decoration, educated men, on the contrary, believed that women should be given a chance to speak in major decisions, and supported women in both a productive and community role. However, female participants also mentioned that in accepting the productive role, they cannot compromise on their reproductive role and thus must bear double the burden 
of responsibility. The uneducated women from the lower middle SES further mentioned that they are not always comfortable in negotiating the use of FP methods with their husbands and families. Nonetheless, their seemingly greater concern regarding the health and quality of their children's lives makes them initiate discussion on FP decisions.

\section{Category 3: Women Autonomy}

The third category emerges only from the data of female participants.

As per female participants, inclusive of many who had shifted from an extended to a nuclear family system, while an extended family system disregards a woman's autonomy, puts her under the pressure of conceiving a child soon after marriage, and deprives the couple of the privacy and time required for FP, a nuclear family system will not only provide the couple autonomy in their personal reproductive and professional lives but may also help her break the vicious cycle of gender discrimination in FP decisions by enabling her to train their children about gender equality with full freedom. A despaired woman mentioned:

"After (the birth of) my baby girl, when I used the injections my mother-in-law verbally abused me. She said that I am a woman of bad character, because I have used injections. She further said that I should produce as many children as she wants and that the use of FP will develop diseases in me that will lead to death. (Uneducated female participant 12 from the lower middle SES)

Female participants mentioned that the type of marriage has an impact on women's autonomy. They shared that in arranged marriages, there was a lack of the required understanding in a couple about FP matters, regardless of the duration of their marriage. In arranged marriages, some participants were not given a chance to meet their would-be spouse, who after marriage would be their sexual partner. This may lead to lack of support for her from her husband, thus leading to a few female respondents feeling disempowered in FP decisions. Female participants mentioned that they used FP methods in secrecy because they were concerned about their health and their children's life, which hampered them from sharing things with their husbands since they felt that on doing so, they would be subjected to blame and suspicion and would have to face abuse from their in-laws and husbands.

"My husband wants to have more children, but I do not favour it. It is because I know it is my duty that I have to (manage) everything, which will not be possible for me if there are more children... I use ECP secretly to prevent (pregnancy). I have not shared this with him, otherwise he will misunderstand me. That's why I am using FP (in secrecy)! He does not like injections, tablets, and all other things (FP methods). As I am a working woman, he may think what am I doing when I am not at home?"(Educated, working woman 09)

However, a few women also mentioned in-laws being supportive by covering up their daughter-in-law's mistakes in arranged marriages, as opposed to in a love marriage.

\section{Category 4: Mind the Gap/Taming the Women}

Generally, participants felt that although a woman looks towards her spouse to avoid maltreating her, her compromising and passive nature contrasted with her spouse's superior, influential, masculine, and dominant nature prevents her from refusing him the pleasure of unprotected sex because doing so would go against his ego, thus labelling the assertive woman as shameless. This causes a woman to lose control of her body and hence prevents her from negotiating and communicating her wishes regarding FP decisions to her husband and in-laws, thus creating gender disparity in our society. Moreover, girls getting married at an early age are not mature enough which makes them suppressed and dependent on others so that by the time they gain maturity, decision making on FP matters is heavily influenced by others in the family. Female participants shared that being financially dependent on husbands suppresses their decision making, that a woman is discriminated against and also has fewer reproductive rights with more roles and responsibilities to perform, such as fulfilling household chores even during pregnancy and in the post-partum period without receiving any recognition for it. A 40-yearold female participant stated:

"A wife is not a machine who will keep on producing children. He (husband) does not allow me to use FP methods. If he (husband) has his way, then I would be pregnant right now. But, it is me who tries to be cautious." (Female participant with six para, from lower middle SES 12)

The participant shared that the blame of side effects of FP methods, baby's gender, unplanned pregnancy, and infertility, is mostly passed on to a woman who alone is held accountable. However, some participants mentioned that some husbands, who care for their wives, allow them to use FP methods. While educated participants from the upper middle SES emphasized that girls are not given their rights since childhood, young educated men mentioned that men can compromise on their pleasure and use condoms to care for their wives' health. Some educated male participants also hinted at upcoming egalitarian gender dynamics by sharing that in some communities, modern 
gender roles can be observed. Both male and female participants verbalized that due to gender inequality regarding FP decisions, women have experienced not only verbal, but also physical, emotional, sexual, and psychological violence.

"I asked her to have medicine as I forgot to get condoms for intercourse. She refused and we had an argument. Thus, I got short tempered and slapped her; then we slept apart." (Male uneducated participant 06)

While male participants mentioned that they execute their anger and frustration on someone less powerful, like children and women in the family, females mentioned that having an extramarital affair with other women has been a usual way to taunt, blame, and abuse a woman. Females shared that in an eastern society, women accused of ruining the harmony in a family are divorced and so they, being concerned about a disturbed family's impact on the academic performance and mental health of their children, do not speak up for their rights.

"She has to agree with it (husband's decisions on FP) whether it is right or not. I believe that if a woman disobeys her husband, she will be at a loss. If she will not agree, the husband will fulfil his desires through other means. The benefit is of the husband and the loss is of the wife. She is at loss if she does not follow the husband's decision and does not obey him. I think that if a person is not getting anything at home he will get that from outside. For example, if I want to have a burger and it is not cooked at home; definitely I will go outside to have it." (Uneducated male participant 05 from lower middle SES)

Moreover, an example of lack of awareness leading to misuse/overuse of FP methods was that the husband of a young female participant pressurized her for hysterectomy in her reproductive age to prevent her from remarrying in case of any uncertainty. Afterwards, she became aware that hysterectomy is a permanent procedure and her husband began to use emotional violence by threatening her with divorce if she did not follow his orders. Lastly, while female participants verbalized that women are human and thus should be treated in a humane manner, one of the male participants interestingly mentioned that females can also be violent towards their husbands. Apparently, some couples do take mutual decisions on FP matters, but the common finding of this study was that women are bound to agree to men's decision, regardless of their willingness and knowledge about FP.

\section{Category 5: Way Forward}

Most participants mentioned that empowering women through education and financial liberty can facilitate in solving problems of gender discrimination. This can give equal reproductive rights to both genders. "Being educated makes women in a position to stand for themselves." (Educated male participant 03) Educated young male participants emphasized the pronounced role of the print and electronic media while educated women pointed out the critical role of parents in raising children to create a society where gender equality is respected. Along with that, the role of NGOs, government, community awareness lectures, and telephonic assistance, were also highlighted to encourage people to avail FP services.

\section{Discussion}

Not only is there a dearth of studies examining this topic, but also the low acceptance rate of FP, the low $30 \%$ Contraceptive Prevalence Rate (CPR) in Pakistan (51-53), the negligible 0.5\% increase per year in FP usage since 1964 (52) and the alarming number of 17 million Pakistani women still not utilizing FP methods suggests that there is a dire need to overcome unmet FP demands $(51,53)$.

\section{Superficial/Peripheral Roots (Factors) Affecting FP Decisions}

The study shows that overall, the society is practicing FP to improve mother's health and prevent multiple pregnancies because otherwise children's needs remain unfulfilled due to financial constraints and growing expenses of more children; the two driving factors facilitating FP usage which have been discovered by this, as well as other studies $(34,36,54)$, to compel couples, and particularly male partners, to try to keep the family size smaller. Additionally, there is a fear of expenses in medical care associated with the use of FP; for example, fixing Intrauterine Contraceptive Device (IUCD), inserting vaginal ring, and getting treated in case of side effects developed by FP, thus enhancing financial constraints. However, in line with other studies in developing countries, $(42,54)$ this study found that FP usage could arouse perceptions of mistrust, suspicion, and spouse's betrayal in a couple's marital life if the man corroborated his wife's usage of FP methods to her not wanting to get pregnant and not wanting to compromise on her sexual desires at the same time. This behaviour is reinforced by the notion that the number of children indicates a woman's love for her husband and emphasizes the need for premarital counselling practices to make couples aware of FP related challenges and solutions to them like being in harmony with the future spouse in reproductive matters would be a source of satisfaction. 
Moreover, while women, in other societies, are now being permitted to work, this changing gender role and the facilitator of "men being dependent" on earning women is not an evident finding in our study because women are not welcomed open heartedly to participate in the financial wellbeing of the family. In fact, even employed women in other countries are not financially independent because they are burdened with both the productive and reproductive role without being duly recognized for either while it is the men who actually decide how money earned by the woman is to be used. Hence, this implies the need for women's financial independence because that will empower women to make major decisions, to help manage the household budget, and thus realize that since raising more children demands more money, it would be worthwhile to invest some money in FP.

The barriers to FP usage discovered by the study were: pressures of the extended family, religious misinterpretations, and fear of side effects, the last of which has also been identified by other studies $(26,42)$. Moreover, while our study's participants mentioned misconceptions, like developing cancer, mental disorders, infertility, death and condoms and other FP methods causing TB and AIDS, multiple studies have also shown that myths like contraceptives causing infertility and being against socio-cultural norms, etc make teaching couples about FP more difficult (55-57). Therefore, education and affiliation with health care professionals can act as authentic sources of information pertaining to FP methods and their appropriateness in any particular case. All these barriers arise because despite the fact that FP programs in Pakistan have been working for several years to make contraceptives available and accessible for the population, improper and insufficient budget allocation (58) for contraceptive procurement and the absence of any formally channelized evaluation systems for programs and their outcomes (53)(Ahmed, 2013) deteriorate the quality of FP programs, thereby not addressing the needs of the Pakistani population (Ahmed, 2013).

Another important aspect identified in this study was that for the society, the couple, being responsible for rearing, grooming, and making their children socially viable, will appear as a respectable entity that mutually discusses and sorts out their reproductive issues. However, even educated women and those belonging to the health care field are not getting equal opportunities to participate actively in FP decisions because in reality, there are deep factors affecting FP decisions.

\section{Deep Roots/Taproots (Factors) Affecting FP Decisions}

Our study, in consistence with previous ones $(14,54)$, mentioned that men have masculine traits, like being firm and authoritative. In contrast, women, being dictated to stay passive since childhood (14), are, in their own homes, and particularly in uneducated families, expected to compromise as per wishes of the male family members. Therefore, in their marital life, they become devoid of their reproductive rights, stay silent in response, and are only involved in making minor decisions that have no significant impact. With respect to Heise's model ((59)-Figure 2), the study found that at the community level, a woman's lower socio-economic status makes her less empowered to make decisions while, at the societal level, in line with previously conducted studies traditional gender roles and responsibilities were found to limit her exposure to the egalitarian approaches of the outside world by confining her to perform all unrecognized household chores alone even in the pregnancy and post-partum period $(15-17,26,60)$.ali et al Furthermore, as confirmed by other studies too, women are confined to their reproductive role while men are given the edge of being assertive and bold since having the productive role of breadwinner renders them heads of the family and in charge of the major decision making $(26,42)$ even though their egoistic nature tends to make them bossy decision makers with the responsibility of FP decisions, pregnancy prevention or conception, baby's sex, and the blame for contraceptives' side effects mostly falling illegitimately on women alone.

Moreover, this study has uniquely revealed that at the relation level of Heise's model, the type of marriage and the role of an extended family are factors compromising a woman's autonomy and so compromising her stand on FP decisions as well. This is so because the dominating traditional mindsets of elderly women in extended families do not allow daughters-in-law to practice what they believe. Similarly, in case of a love marriage, although there is greater mutual understanding in the couple, the hard time the wife is given by her inlaws, makes it more difficult for her to divert from the traditionally assigned roles and responsibilities. Mutual understanding, however, is important because sometimes when women are motivated to use FP and men are not, the pressure of gender disparity may persuade them to hide their usage of FP methods from their sexual partners (42). This not only violates the husband's equal right of being involved in reproductive decisions but may also lead to him mistrusting his wife's fidelity in case he gets informed about her secret usage of FP methods. This weakens the couple's marital relation in the long run. On the other hand, in consistence with other studies, male partners are sometimes also at a disadvantage if FP is considered only a female's task $(26,30)$. Therefore, in corroboration with the study conducted in sub-Saharan Africa (61), conducting campaigns to motivate and hence involve men in FP matters will encourage them to make decisions and take greater and equal responsibility in pregnancy prevention, in fulfilling unmet contraceptive needs and in other reproductive matters. Moreover, by men being more open to help women, women too will have more control over their reproductive rights. 
Our study was also the first of its kind to reveal early marriage as one of the issues leading to decreased women empowerment in reproductive decisions. This is because marrying at an early age means the girl is not mature enough so the conventional pattern of decision-making regarding FP matters becomes fixed, without her input. Later, on attaining maturity, it is too late for her to take her position in the family about her reproductive decisions. Additionally, at times, women also need to be accompanied by extended family members or their spouses to avail reproductive health services. Despite understanding the unequal treatment, women stay silent because they either fear violence or fear that being assertive will lead to divorce. Such violence, as shown by another study too (54), may take many torturous forms ranging from taunts, and abusive language to physical violence, and emotional pain. It is also this fear of violence that prevents women from negotiating with respect to the use of FP methods; a finding also revealed in many other studies $(11,24,39)$. One of the worst forms of violence is a direct consequence of a woman being unaware of her reproductive rights. The study presented the novel perspective of a woman who, under pressure from her husband, underwent hysterectomy during her reproductive age and later, on becoming aware, questioned as to why only she had to undergo this invasive procedure when her husband could have undergone vasectomy himself. This is also given the fact that many methods of FP are available for young women to determine the frequency of childbirth like injectables, implants, and IUCDs $(40,53)$. However, it is believed that the husband of a wife who has undergone a permanent procedure of FP can remarry as a threat to his previous wife, who, being unable to get pregnant, cannot remarry and therefore, must fulfil everything asked by her husband to protect her family. Moreover, a woman may also have to undergo multiple pregnancies to give birth to the required number of male children and may also be subjected to blame for the birth of a female child even though the gene determining the child's sex comes from the father. Therefore, women should be counselled before opting for any surgical procedure at a young age and this study, in line with Heise's model, reasons that addressing individual factors like early marriages, lack of education on reproductive rights, and lack of financial independence can help prevent violence (62) and help overcome gender disparity.

\section{Limitations}

The current study is not transferable because due to insufficient time, it was limited to the urban setting only and so, it is recommended that a replication of this study be carried out in the rural parts of Pakistan as well. Secondly, the sensitivity of this topic did not allow enrolling unmarried participants because although the use of FP may be a burgeoning concern for unmarried individuals who are sexually active, in the Pakistani society, only married individuals, are supposed to be sexually active and associated with reproductive and FP matters. Furthermore, due to the sensitive nature of the topic, participants might have felt reluctant to reveal their personal matters. Nonetheless, conducting the study on both genders, building rapport and culturally sensitive probes, and directly involving the researcher in the process of data collection and analysis uplifts the quality of the data by preventing the nuances and essential details from being overlooked, thereby helping to bridge the gap in existing literature on this topic in Pakistan.

\section{Conclusion}

Our study results emphasized that, apart from superficial factors influencing FP decision making, such as, awareness and understanding about FP, there are in fact other deep roots/tap roots inclusive of gender norms, women autonomy, and gender discrimination which influence reproductive decisions and thus must be strongly addressed by the school curricula and by nurses and other HCWs to help bring about a positive change in our society. Further qualitative and quantitative researches must also be conducted to further assess the perceptions of key stake holders of the society about influence of gender roles on FP. Moreover, multi prong approach to involve key stakeholders (sociologists, educationists, religious leaders, policy makers) must be employed to modify the perception, and attitude around the FP decision.

\section{List Of Abbreviations}

AIDS Acquired Immune Deficiency Syndrome

AKUH Aga Khan University Hospital

CPR Contraceptive Prevalence Rate

ERC Ethical Review Committee

FP Family Planning

IUCD Intrauterine Contraceptive Device 
TB Tuberculosis

\section{Declarations}

We declare that none of the authors have any conflict of interest.

\section{Ethics approval and consent to participate}

The study was approved by Aga Khan University Ethical Review Committee, letter No. 3338-SON-ERC-14 (see Appendix)

\section{Consent for publication}

We give consent to the journal to publish.

\section{Availability of data and materials}

The datasets used and/or analysed during the current study are available from the corresponding author on reasonable request.

\section{Competing interests}

The authors declare that they have no competing interests.

\section{Funding}

No funding or grant was given.

\section{Authors' Contributions}

ZS, MMK, SS and TSA were involved in development of the idea of the study. ZS obtained ERC approval for conducting the study and undertook data collection. WA and TSA wrote the final manuscript. MMK, SS and TSA facilitated ERC approval and were involved in the overall revision and supervision of the manuscript. All authors read and approved the final manuscript.

\section{Acknowledgements}

The authors would like to acknowledge the editorial support provided by Ms. Fatima Shahabuddin, Specialist Academic English, and the detailed feedback provided by Mr. Roger Smith, English mentor/tutor, during the write-up stage. I would also like to thank Dr. Anita Allana who allowed me to attend her sessions on "gender" and thus helped me to further clarify my concepts. I am grateful to Anique Arshad Siddiqui, student at School of Public Health, SZABIST, for assisting with the submission process of the manuscript. Lastly, I would also like to extend my immense gratitude to Dean, Dr. Raisa Gul, the Director of the MSc Nursing program, Dr. Rubina Barolia and the Coordinator, Ms. Saadia Dawoodani for their consistent support, dedication, and motivation.

\section{References}

1. Adana F, Arslantaş H, Ergin F, Biçer N, Kıranşal N, Şahin S. Views of male university students about social gender roles; an example from east of Turkey. Journal of Family Violence. 2011;26(7):519-26.

2. Organization WH. Gender, women and primary health care renewal: a discussion paper: World Health Organization; 2010.

3. Ali PA, Gavino MIB. Violence against women in Pakistan: A framework for analysis. Journal-Pakistan Medical Association. 2008;58(4):198. 
4. Khalaf ZF, Low WY, Ghorbani B, Khoei EM. Perception of masculinity amongst young Malaysian men: a qualitative study of university students. BMC public health. 2013;13(1):1-8.

5. Eriksson J, Dellve L, Eklöf M, Hagberg M. Early inequalities in excellent health and performance among young adult women and men in Sweden. Gender medicine. 2007;4(2):170-82.

6. Van Gundy K, Schieman S, Kelley MS, Rebellon CJ. Gender role orientations and alcohol use among Moscow and Toronto adults. Social science \& medicine. 2005;61(11):2317-30.

7. Gordon DM, Hawes SW, Reid AE, Callands TA, Magriples U, Divney A, et al. The many faces of manhood: Examining masculine norms and health behaviors of young fathers across race. American journal of men's health. 2013;7(5):394-401.

8. Connell R. Work/life balance, gender equity and social change. Australian Journal of Social Issues. 2005;40(3):369-83.

9. Carver LF, Vafaei A, Guerra R, Freire A, Phillips SP. Gender differences: Examination of the 12-item Bem Sex Role Inventory (BSRI-12) in an older Brazilian population. PloS one. 2013;8(10):e76356.

10. Byron G, Örnemark C. Gender equality in Swedish development cooperation: Citeseer; 2010.

11. Parveen R. Gender-based violence in Pakistan: a scoping study. 2011.

12. Davis SN. Gender ideology construction from adolescence to young adulthood. Social Science Research. 2007;36(3):1021-41.

13. Fulcher M, Coyle EF. Breadwinner and caregiver: A cross-sectional analysis of children's and emerging adults' visions of their future family roles. British Journal of Developmental Psychology. 2011;29(2):330-46.

14. Ali TS, Krantz G, Gul R, Asad N, Johansson E, Mogren I. Gender roles and their influence on life prospects for women in urban Karachi, Pakistan: a qualitative study. Glob Health Action. 2011;4:7448.

15. Hatcher AM, Romito P, Odero M, Bukusi EA, Onono M, Turan JM. Social context and drivers of intimate partner violence in rural Kenya: implications for the health of pregnant women. Culture, health \& sexuality. 2013;15(4):404-19.

16. Sommer M, Likindikoki S, Kaaya S. Boys' and young men's perspectives on violence in Northern Tanzania. Culture, health \& sexuality. 2013;15(6):695-709.

17. McCarry M. Becoming a 'proper man': Young people's attitudes about interpersonal violence and perceptions of gender. Gender and Education. 2010;22(1):17-30.

18. Misra J, Lundquist JH, Templer A, editors. Gender, Work Time, and Care Responsibilities Among Faculty 1. Sociological Forum; 2012: Wiley Online Library.

19. Rattani S. Working and Nonworking Women's descriptions and experiences of their roles in Society. International Journal of Humanities and Social Science. 2012;2(19):230.

20. Tsui AO, Wasserheit JN, Haaga JG. Reproductive health in developing countries: expanding dimensions, building solutions. 1997.

21. Khan MM, Zafar MI, Ali T, Ahmad A. Effect of socio-economic, cultural and demographic factors on woman reproductive health. Pak J Agri Sci. 2009;46(4):308-14.

22. Farid-ul-Hasnain S, Johansson E, Mogren I, Krantz G. Young adults' perceptions on life prospects and gender roles as important factors to influence health behaviour: A qualitative study from Karachi, Pakistan. Global journal of health science. 2012;4(3):87.

23. Story WT, Burgard SA. Couples' reports of household decision-making and the utilization of maternal health services in Bangladesh. Social science \& medicine. 2012;75(12):2403-11.

24. East L, Jackson D, O’Brien L, Peters K. Condom negotiation: experiences of sexually active young women. Journal of Advanced Nursing. 2011;67(1):77-85.

25. Ali TS. Living with violence in the home: Exposure and experiences among married women, residing in urban Karachi, Pakistan: Inst för folkhälsovetenskap/Dept of Public Health Sciences; 2011.

26. Adams MK, Salazar E, Lundgren R. Tell them you are planning for the future: gender norms and family planning among adolescents in northern Uganda. International Journal of Gynecology \& Obstetrics. 2013;123:e7-e10.

27. Marcos JM, Avilés NR, del Río Lozano M, Cuadros JP, Calvente MdMG. Performing masculinity, influencing health: a qualitative mixedmethods study of young Spanish men. Global health action. 2013;6(1):21134.

28. Schraiber LB, Barros CRdS, Couto MT, Figueiredo WS, Albuquerque FPd. Men, masculinity and violence: a study in primary health care services. Revista Brasileira de Epidemiologia. 2012;15:790-803.

29. Quevedo-Gómez MC, Krumeich A, Abadía-Barrero CE, Pastrana-Salcedo E, van den Borne H. Machismo, public health and sexualityrelated stigma in Cartagena. Culture, health \& sexuality. 2012;14(2):223-35.

Page 13/18 
30. Smith JL, Fenwick J, Skinner R, Merriman G, Hallett J. Young males' perspectives on pregnancy, fatherhood and condom use: where does responsibility for birth control lie? Sexual \& Reproductive Healthcare. 2011;2(1):37-42.

31. Marchi N, De Alvarenga A, Osis M, Bahamondes L. Contraceptive methods with male participation: a perspective of Brazilian couples. International nursing review. 2008;55(1):103-9.

32. Kamal A, Pervaiz MK. Factors Affecting the Family Size in Pakistan: Clog-log Regression Model Analysis. Journal of Statistics. $2011 ; 18(1)$.

33. Hamid S, Stephenson R, Rubenson B. Marriage decision making, spousal communication, and reproductive health among married youth in Pakistan. Global health action. 2011;4(1):5079.

34. Chapagain M. Masculine interest behind high prevalence of female contraceptive methods in rural Nepal. Australian Journal of Rural Health. 2005;13(1):35-42.

35. Mullany BC, Hindin MJ, Becker S. Can women's autonomy impede male involvement in pregnancy health in Katmandu, Nepal? Social science \& medicine. 2005;61(9):1993-2006.

36. Hamid S, Stephenson R, Rubenson B. Marriage decision making, spousal communication, and reproductive health among married youth in Pakistan. Glob Health Action. 2011;4:5079.

37. Haider S, Todd C, Ahmadzai M, Rahimi S, Azfar P, Morris JL, et al. Childbearing and contraceptive decision making amongst Afghan men and women: a qualitative analysis. Health Care Women Int. 2009;30(10):935-53.

38. Rizvi N, Khan KS, Shaikh BT. Gender: shaping personality, lives and health of women in Pakistan. BMC women's health. 2014;14(1):18.

39. Upadhyay UD, Karasek D. Women's empowerment and ideal family size: an examination of DHS empowerment measures in SubSaharan Africa. International perspectives on sexual and reproductive health. 2012:78-89.

40. Oyedeji O, Cassimjee R. A gendered study of young adult contraceptive use at one university in KwaZulu-N atal. Curationis. 2006;29(3):7-14.

41. Roberts AB, Oyun C, Batnasan E, Laing L. Exploring the social and cultural context of sexual health for young people in Mongolia: implications for health promotion. Social science \& medicine. 2005;60(7):1487-98.

42. Mosha I, Ruben R, Kakoko D. Family planning decisions, perceptions and gender dynamics among couples in Mwanza, Tanzania: a qualitative study. BMC public health. 2013;13(1):1-13.

43. Onwuegbuzie AJ, Leech NL. Sampling designs in qualitative research: Making the sampling process more public. Qualitative Report. 2007;12(2):238-54.

44. Blanc AK, Wolff B. Gender and decision-making over condom use in two districts in Uganda. African journal of reproductive health. 2001:15-28.

45. Adhi M, Hasan R, Shoaib S, Tauheed S. Age and symptomatology of menopause in Karachi, Pakistan. Pakistan Journal of Physiology. 2007;3(1):41-4.

46. Naeem M, Khan MZ-U-I, Abbas SH, Adil M, Khan A, Naz SM, et al. Coverage and factors associated with tetanus toxoid vaccination among married women of reproductive age: a cross sectional study in Peshawar. Journal of Ayub Medical College Abbottabad. 2010;22(3):136-40.

47. Creswell JW, Poth CN. Qualitative inquiry and research design: Choosing among five approaches: Sage publications; 2016.

48. Polit DF, Beck CT. Nursing research : generating and assessing evidence for nursing practice. 9 ed: Wolters Kluwer Health/Lippincott Williams \& Wilkins; 2012. 802 p.

49. Murphy F, Yielder J. Establishing rigour in qualitative radiography research. Radiography. 2010;16(1):62-7.

50. Wood MJ, Ross-Kerr JC. Basic steps in planning research: From question to proposal: Jones and Bartlett; 2011.

51. Studies NIoP, International I. Pakistan demographic and health survey 2012-13. NIPS and ICF International Islamabad, Pakistan, and Calverton, Maryland, USA; 2013.

52. Shaikh BT, Azmat SK, Mazhar A. Family planning and contraception in Islamic countries: a critical review of the literature. JPMA The Journal of the Pakistan Medical Association. 2013;63(4 Suppl 3):S67-72.

53. Khan A, Khan A. Family Planning in Pakistan: An Overview. Research and Development Solutions, Policy Briefs Series No. $2012 ; 1$.

54. Schuler SR, Rottach E, Mukiri P. Gender norms and family planning decision-making in Tanzania: a qualitative study. Journal of Public Health in Africa. 2011;2(2). 
55. Azmat SK, Mustafa G, Hameed W, Ali M, Ahmed A, Bilgrami M. Barriers and perceptions regarding different contraceptives and family planning practices amongst men and women of reproductive age in rural Pakistan: a qualitative study. Pak J Public Health.

2012;2(1):1-8.

56. Guidelines for Family Planning Communication. In: Ministry of Health HEU, editor. Malawi2011.

57. Pokuaa EA, Aboba M. Challenges in addressing misconceptions with family planning: a nurse's perspective. Ghana; 2013.

58. Khan A, Khan A. Family Planning Services In Pakistan. Research and Development Solutions, Policy Briefs Series No 2.2012.

59. Heise LL. Violence against women: An integrated, ecological framework. Violence against women. 1998;4(3):262-90.

60. Ayenibiowo K, Akinbode G, Ayodeji F. Gender and Ethnic Differences in Young Adults Perception of Appropriateness of Some Domestic Activities in Nigeria. British Journal of Arts and Social Sciences, 2 (2); 140. 2012;156.

61. Vouking MZ, Evina CD, Tadenfok CN. Male involvement in family planning decision making in sub-Saharan Africa-what the evidence suggests. The Pan African Medical Journal. 2014;19.

62. Glasier A, Gülmezoglu AM, Schmid GP, Moreno CG, Van Look PF. Sexual and reproductive health: a matter of life and death. The Lancet. 2006;368(9547):1595-607.

\section{Appendix}

Tables

Table 1: Demographic Data of married Male Participants

\begin{tabular}{|c|c|c|c|c|c|c|c|c|c|c|}
\hline Code & $\begin{array}{l}\text { Socio } \\
\text { economic } \\
\text { status } \\
\text { (SES) }\end{array}$ & $\begin{array}{l}\text { Family } \\
\text { income } \\
\text { (Pakistani } \\
\text { rupees) }\end{array}$ & Age & $\begin{array}{l}\text { Educational } \\
\text { level }\end{array}$ & $\begin{array}{l}\text { Working } \\
\text { status }\end{array}$ & $\begin{array}{l}\text { Profession/ } \\
\text { Employment } \\
\text { status }\end{array}$ & $\begin{array}{l}\text { Mother } \\
\text { tongue }\end{array}$ & $\begin{array}{l}\text { Type of } \\
\text { family }\end{array}$ & $\begin{array}{l}\text { Duration } \\
\text { of } \\
\text { marriage }\end{array}$ & $\begin{array}{l}\text { Number, } \\
\text { age, and } \\
\text { sex of } \\
\text { child(ren) }\end{array}$ \\
\hline 01 & $\begin{array}{l}\text { Upper } \\
\text { middle }\end{array}$ & 70,000 & $\begin{array}{l}33 \\
\text { years }\end{array}$ & $\begin{array}{l}\text { Masters } \\
\text { (MBA) }\end{array}$ & Working & $\begin{array}{l}\text { Business } \\
\text { man/ Self } \\
\text { employed }\end{array}$ & Urdu & Nuclear & 4 years & $\begin{array}{l}1 \text { child } \\
\text { (Male: } 2 \\
\text { years) }\end{array}$ \\
\hline 02 & $\begin{array}{l}\text { Upper } \\
\text { middle }\end{array}$ & 100,000 & $\begin{array}{l}29 \\
\text { years }\end{array}$ & $\begin{array}{l}\text { Bachelors } \\
\text { (B. com) }\end{array}$ & Working & $\begin{array}{l}\text { Service } \\
\text { Manager/ } \\
\text { Private }\end{array}$ & Memoni & Extended & 7 years & $\begin{array}{l}1 \text { child } \\
\text { (Male: } 5 \\
\text { years ) }\end{array}$ \\
\hline 03 & Middle & 35,000 & $\begin{array}{l}44 \\
\text { years }\end{array}$ & $\begin{array}{l}\text { Bachelors } \\
\text { (B.com) }\end{array}$ & Working & $\begin{array}{l}\text { Business } \\
\text { man/ Self- } \\
\text { employed/ } \\
\text { Owner }\end{array}$ & Gujrati & Nuclear & 20 years & $\begin{array}{l}2 \\
\text { children } \\
\text { (Female: } \\
16 \text { years; } \\
\text { Male: } 12 \\
\text { years) }\end{array}$ \\
\hline 04 & Middle & 40,000 & $\begin{array}{l}33 \\
\text { years }\end{array}$ & $\begin{array}{l}\text { Bachelors } \\
\text { (B.A.) }\end{array}$ & Working & $\begin{array}{l}\text { Service/ } \\
\text { Employee }\end{array}$ & Punjabi & Extended & 5 years & $\begin{array}{l}3 \\
\text { children } \\
\text { (Male: } 4, \\
2.5, \text { and } \\
1.2 \\
\text { years) }\end{array}$ \\
\hline 05 & $\begin{array}{l}\text { Lower } \\
\text { middle }\end{array}$ & 8,000 & $\begin{array}{l}36 \\
\text { years }\end{array}$ & Class 4 & Working & $\begin{array}{l}\text { Driver } \\
\text { /Employee }\end{array}$ & Punjabi & Nuclear & $\begin{array}{l}10.5 \\
\text { years }\end{array}$ & $\begin{array}{l}1 \text { child } \\
\text { (Female: } \\
9.5 \text { years; } \\
\text { two } \\
\text { children } \\
\text { expired) }\end{array}$ \\
\hline 06 & $\begin{array}{l}\text { Lower } \\
\text { middle }\end{array}$ & $\begin{array}{l}1500 \text { to } \\
9,000 \\
\text { (wages) }\end{array}$ & $\begin{array}{l}29 \\
\text { years }\end{array}$ & Illiterate & Working & $\begin{array}{l}\text { Labour/ } \\
\text { Works on } \\
\text { wages/worker }\end{array}$ & Sindhi & Extended & 18 years & $\begin{array}{l}4 \\
\text { children } \\
\text { (Male:17 } \\
\text { and12 } \\
\text { years; } \\
\text { Female: } \\
9 \text { and } 7 \\
\text { years) }\end{array}$ \\
\hline
\end{tabular}


Table 2: Demographic Data of married Female Participants

\begin{tabular}{|c|c|c|c|c|c|c|c|c|c|c|}
\hline Code & SES & $\begin{array}{l}\text { Family } \\
\text { income } \\
\text { (Pakistani } \\
\text { rupees) }\end{array}$ & Age & $\begin{array}{l}\text { Education } \\
\text { level }\end{array}$ & $\begin{array}{l}\text { Working } \\
\text { status }\end{array}$ & $\begin{array}{l}\text { Profession/ } \\
\text { Employment } \\
\text { status }\end{array}$ & $\begin{array}{l}\text { Mother } \\
\text { tongue }\end{array}$ & $\begin{array}{l}\text { Type of } \\
\text { family }\end{array}$ & $\begin{array}{l}\text { Duration } \\
\text { of } \\
\text { marriage }\end{array}$ & $\begin{array}{l}\text { Number, } \\
\text { age, and } \\
\text { sex of } \\
\text { children }\end{array}$ \\
\hline 07 & $\begin{array}{l}\text { Upper } \\
\text { middle }\end{array}$ & 80,000 & $\begin{array}{l}29 \\
\text { years }\end{array}$ & $\begin{array}{l}\text { Diploma } \\
\text { holder }\end{array}$ & Working & $\begin{array}{l}\text { Designer and } \\
\text { beautician/ } \\
\text { Self employed }\end{array}$ & Gujrati & Nuclear & 6 years & $\begin{array}{l}1 \text { child } \\
\text { (Male: } 5 \\
\text { years) }\end{array}$ \\
\hline 08 & $\begin{array}{l}\text { Upper } \\
\text { middle }\end{array}$ & 100,000 & $\begin{array}{l}40 \\
\text { years }\end{array}$ & $\begin{array}{l}\text { Bachelors } \\
\text { (B.A.) }\end{array}$ & $\begin{array}{l}\text { Not } \\
\text { working }\end{array}$ & $\begin{array}{l}\text { Housewife/ } \\
\text { Unemployed }\end{array}$ & Urdu & Nuclear & 16 years & $\begin{array}{l}2 \text { children } \\
\text { (Female:13 } \\
\text { years; } \\
\text { Male: } 9 \\
\text { years) }\end{array}$ \\
\hline 09 & Middle & 22,000 & $\begin{array}{l}42 \\
\text { years }\end{array}$ & $\begin{array}{l}\text { Bachelors } \\
\text { (B.A.) }\end{array}$ & Working & $\begin{array}{l}\text { Operator/ } \\
\text { Employed }\end{array}$ & Urdu & Nuclear & 20 years & $\begin{array}{l}2 \text { children } \\
\text { (Female: } \\
19 \text { and } 12 \\
\text { years) }\end{array}$ \\
\hline 10 & Middle & 19,000 & $\begin{array}{l}26 \\
\text { years }\end{array}$ & $\begin{array}{l}\text { Bachelors } \\
\text { (B.com) }\end{array}$ & $\begin{array}{l}\text { Not } \\
\text { working }\end{array}$ & $\begin{array}{l}\text { Housewife/ } \\
\text { Unemployed }\end{array}$ & Urdu & Extended & $\begin{array}{l}3.5 \\
\text { years }\end{array}$ & $\begin{array}{l}1 \text { child } \\
\text { (Female: } \\
2.5 \text { years) }\end{array}$ \\
\hline 11 & $\begin{array}{l}\text { Lower } \\
\text { middle }\end{array}$ & 8,000 & $\begin{array}{l}28 \\
\text { years }\end{array}$ & Illiterate & $\begin{array}{l}\text { Not } \\
\text { working }\end{array}$ & $\begin{array}{l}\text { Housewife/ } \\
\text { Unemployed }\end{array}$ & Punjabi & Extended & $\begin{array}{l}10.5 \\
\text { years }\end{array}$ & $\begin{array}{l}3 \text { children } \\
\text { (Female: } 9 \\
\text { years; } \\
\text { Male: } 8 \\
\text { years and } \\
1 \text { year) }\end{array}$ \\
\hline 12 & $\begin{array}{l}\text { Lower } \\
\text { middle }\end{array}$ & 4,000 & $\begin{array}{l}40 \\
\text { years }\end{array}$ & Illiterate & $\begin{array}{l}\text { Not } \\
\text { working }\end{array}$ & $\begin{array}{l}\text { Housewife/ } \\
\text { Unemployed }\end{array}$ & Sindhi & Nuclear & 20 years & $\begin{array}{l}4 \text { children } \\
\text { (Male: } 15 \\
\text { and } 5 \\
\text { years; } \\
\text { Female } 14 \\
\text { and } 13 \\
\text { years) }\end{array}$ \\
\hline
\end{tabular}

\section{Figures}




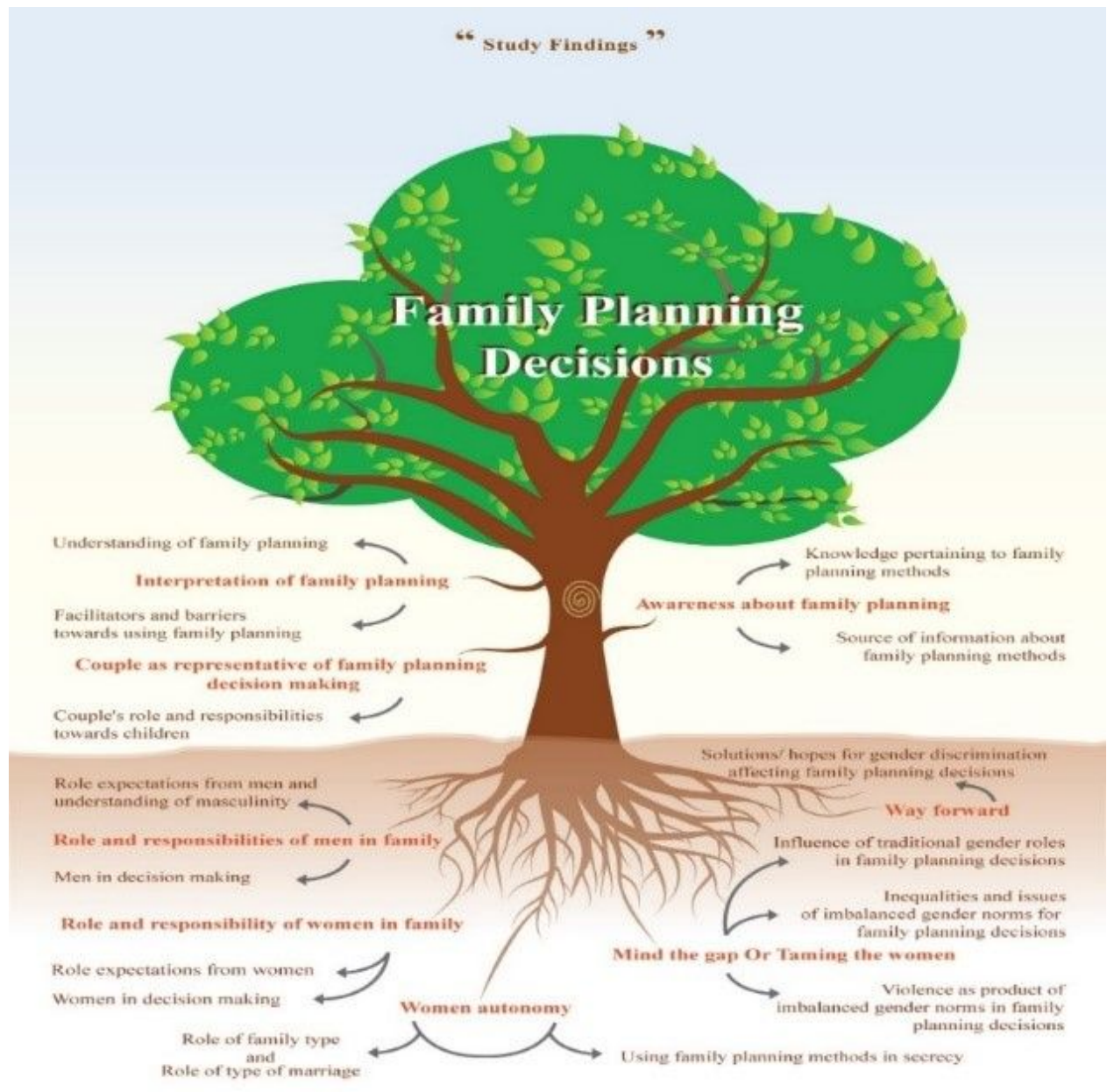

Figure 1

Study Findings 


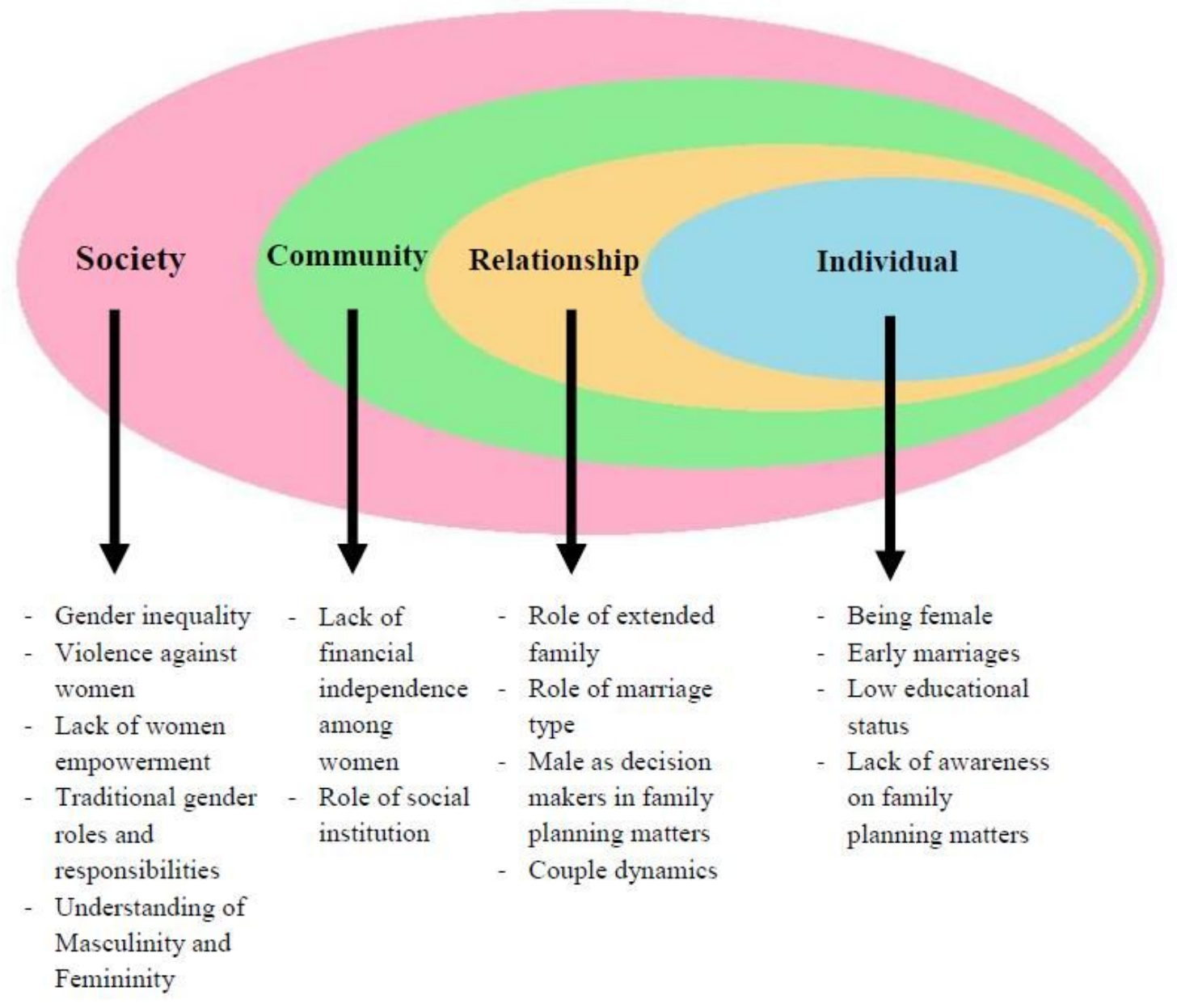

Social ecological model [adapted from Heise (1998)]

Heise LL, Violence against women: an integrated, ecological framework Violence Against Women 1998, 4(3):262-290

The Social ecological model for factors (gender dynamics) influencing family planning decisions (as presented by Heise, 1998)

\section{Figure 2}

The Social ecological model for factor (gender dynamics) influencing FP decisions (as presented by Heise, 1998) 